Original Research Paper

\title{
The Effect of Chitosan Extracted from Green Mussel Shells Perna viridis on Sonneratia caseolaris Mangrove Syrup Preservation
}

\author{
Muhammad Sholahuddin Al Ayyubi ${ }^{{ }^{*}}$, Farikhah $^{1}$, Nur Maulida Safitri ${ }^{1}$ \\ ${ }^{1}$ Aquaculture Study Program, Faculty of Agriculture, Universitas Muhammadiyah Gresik, Indonesia
}

\author{
Article History \\ Received : December $16^{\text {th }}, 2021$ \\ Revised : December 30 ${ }^{\text {th }}, 2021$ \\ Accepted : January $17^{\text {th }}, 2022$ \\ Published : January $24^{\text {th }}, 2022$ \\ *Corresponding Author: \\ Muhammad Sholahuddin Al \\ Ayyubi \\ Universitas Muhammadiyah \\ Gresik, Indonesia \\ Email: \\ alsholahuddinayyubi7@gmail.com; \\ farikhah@umg.ac.id \\ nur.maulida@umg.ac.id
}

\begin{abstract}
Green mussels (Perna viridis) are one of the prospective aquatic resources that can be developed into a high-value commodity. Their shells, on the other hand, are rarely used and discarded; despite the fact that the shells are contain chitosan, which can be used as a food preservative. The purpose of this study is to examine the effect of chitosan administration from green mussel shells on Sonneratia caseolaris mangrove syrup at various concentrations. The experimental design used Completely Randomized Design (CRD) with 7 treatments within 3 replications. The study lasted 30 days in order tho find the best concentration of chitosan as a preservative. The McFarland method was used to evaluate the total dissolved density (Brix), the acidity $(\mathrm{pH})$, the organoleptic study (aroma and color), and the bacterial density. The following treatments were used in this study: P1 to P5 (the addition of 0.1-0.5 ml of green mussel sheel chitosan solution); P6 (the negative control or without the addition of green mussel shell chitosan solution); and P7 (the positive control with the addition of $0.1 \mathrm{ml}$ sodium benzoate $\left(\mathrm{C}_{7} \mathrm{H}_{5} \mathrm{NaO}_{2}\right)$ as commercial preservative). The results showed that the average value of total dissolved density P1-P7 varied between 22-22.46 (Brix); acidity ( $\mathrm{pH}$ ) of P1-P7 ranged between 2-3,1; and the organoleptic test obtained points 5 (neutral) on the aroma and color test. As a conclusion, chitosan derived from green mussel shells $P$. viridis is promising agent to be utilized as a preservative in S. caseolaris mangrove syrup.
\end{abstract}

Keywords: Brix, Chitosan, Organoleptic, $\mathrm{pH}$

\section{Pendahuluan}

Kerang hijau merupakan salah satu komoditas akuatik yang prospektif sehingga dapat dikembangkan menjadi komoditas bernilai ekonomis tinggi. Hal ini disebabkan karena kandungan gizinya yang tinggi, yaitu protein $21,9 \%$, lemak $14,5 \%$, karbohidrat $18,5 \%$, abu 4,3\% dan air 40,8\% (Affandi dan Tang, 2002). Periode budidaya yang relatif pendek serta masa pertumbuhan yang cepat menunjukkan bahwa kerang hijau merupakan komoditas potensial yang dapat dikembangkan melalui kegiatan budidaya (Loekman et al., 2018).

Untuk mendukung sistem perikanan zero waste system, maka semua bagian tubuh dari kerang hijau perlu diamanfaatkan seluruhnya. Limbah cangkang kerang hijau $(\mathrm{CKH})$ dapat dimanfaatkan sebagai pakan ternak maupun kerajinan. Peluang pemanfaatan yang lain adalah sebagai bahan produksi kitin dan kitosan (Costa, 2008). Kitin merupakan senyawa organik yang dapat ditemukan pada kelompok hewan crustacea, insekta, moluska, dan arthropoda. Karena kandungan kitinnya cukup tinggi, cangkang kepiting, udang, kerang dan lobster telah dimanfaatkan sebagai sumber bahan dasar produksi kitin. Hargono et al., (2008) melaporkan kandungan kitosan pada kelompok udang-udangan. Kitosan (turunan kitin) mempunyai berbagai benefit pada berbagai bidang kehidupan. Senyawa kitosan dapat mendegradasi kontaminan, memisahkan air limbah dari protelium, bisa menjadi pelapis benih yang ditanam, bahan antikolesterol, antikoagulan dalam darah, penyerap logam berat (Acosta et al, 2009), preservatif ikan (Ariyani dan Yennie, 2008), dan penyerap zat warna (Tanasale et al, 2012). 
Kerusakan makanan dapat terjadi karena aktifitas mikrobia maupun aktifitas molekul yang ada pada bahan makanan, oleh karena itu perubahan secara fisika-kimia juga mampu mempengaruhi kerusakan makanan (Violando dan Safitri, 2020). Rekayasa proses dengan penambahan bahan pengawet diperlukan karena bahan makanan atau minuman yang mengandung karbohidrat, lemak, protein dan komponen lain akan mengalami perubahan kimia (Kusumaningrum, et al., 2017). Untuk menghambat sekaligus mencegah bahan pangan rusak akibat jamur, bakteri maupun mikroba perlu ditambahkan bahan pengawet (Arini, 2017). Tujuan dari penelitian ini yaitu menganalisis mutu dan pertumbuhan bakteri serta pengaruh pemberian beberapa konsentrasi kitosan pada sirup buah mangrove selama penyimpanan.

\section{Bahan dan Metode}

\section{Ekstraksi Kitosan}

Kutikula dikenal sebagai material penyusun utama pada produksi kitin yang umumnya terdapat pada berbagai jenis crustacea, terutama dari jenis kepiting dan udang. Kitin ditemukan pada jaringan penyusun kompleks dengan protein yang dimana deposit dari $\mathrm{CaCO}_{3}$ membentuk tempurung yang kaku. Interaksi yang berkesinambungan antara protein dengan senyawa kitin sangat erat dan sebagian kecil protein juga terlibat dalam kompleks protein polisakarida (Islem et al., 2015).

Untuk membantu mengeluarkan dua penyusun utama dari kulit udang maupun jenis crustacea diperlukan isolasi senyawa kitin melalui protein dengan deproteinisasi dan kalsium karbonat anorganik melewati demineralisasi. Tidak ada metode standar yang ditetapkan untuk menyiapkan kitin murni. Metode kimiawi dan enzimatik masih digunakan untuk deproteinisasi dan demineralisasi. (Islem et al., 2015) Tahapan deproteinasi dimulai setelah penambahan $\mathrm{NaOH}$ encer untuk melarutkan protein.

\section{Demineralisasi}

Secara garis besar proses demineralisasi dapat dilakukan secara perlakuan asam dengan $\mathrm{CH}_{3} \mathrm{COOH}, \mathrm{HCOOH}, \mathrm{HCl}, \mathrm{HNO}_{3}$ dan $\mathrm{HSO}_{4}$ (Percot et al, 2003; Islem et al, 2015).
Demineralisasi memiliki tujuan menghilangkan mineral, terutama $\mathrm{CaCO}_{3}$. Demineralisasi cukup mudah tercapai karena dengan pelepasan $\mathrm{CO}_{2}$ garam kalsium akan lebih mudah larut dalam air karena $\mathrm{CaCO}_{3}$ telah terdekomposisi sebelumnya.

\section{Deproteinasi}

Beragam kesulitan pada proses deproteinasi dikarenakan karena kuatnya ikatan kimia antara senyawa kitin dan protein. Pengambilan protein keseluruhan dirasa cukup untuk kepentingan aplikasi biomedis, komponen protein yang terdapat pada kerang masih menjadi salah satu penyebab persentase populasi manusia mengalami alergi (Percot et al, 2003; Islem 2015). Dengan menggunakan bahan kimia yang juga mendepolimerisasi biopolimer, proses deproteinisasi dapat dilakukan secara heterogen.

\section{Deasetilasi}

Dalam pandangan kimia, alkali atau asam digunakan sebagai reaksi deasetilasikitin. Karena kerentanan ikatan glikosidik terhadap asam, sehingga reaksi deasetilasi dengan alkali lebih sering digunakan (Hajji et al., 2014). Secara umum reaksi deastilasi kitin adalah reaksi pengubahan gugus asetil $\left(-\mathrm{NHCOCH}_{3}\right)$ pada kitin menjadi gugus amina (- $\left.\mathrm{NH}_{2}\right)$ (Minda et al., 2010).

Proses ekstraksi dimulai dengan pencucian $\mathrm{CKH}$ dengan air mengalir kemudian dioven (Memmert, Type ULM400, Jerman) sampai kering dan dihancurkan dengan mortar hingga menjadi kepingan, selanjutnya dilakukan prosedur demineralisasi dengan $\mathrm{HCl} 0.68 \mathrm{M}$ (w/v; 1/5) selama 24 jam dan dibilas dengan air mengalir sampai menunjukkan $\mathrm{pH}$ air normal (pH 7) Deproteinasi dilakukan menggunakan $\mathrm{NaOH} 0.62 \mathrm{M}(\mathrm{w} / \mathrm{v} ; 1 / 5)$ selama \pm 16 jam, setelah itu dinetralkan dengan dibilas akuades sampai $\mathrm{pH}$ menjadi netral lalu deasetelisasi dengan $\mathrm{NaOH} 25 \mathrm{M}$ (w/v; 1/5) selama 20 jam kemudian dibilas dengan air sampai $\mathrm{pH}$ menjadi netral kemudian dioven sampai benar-benar kering selama \pm 72 jam. Selanjutnya, ekstrak dihaluskan dan disimpan di freezer pada suhu $\pm 4^{\circ} \mathrm{C}$.

\section{Pembuatan Sirup Buah Mangrove}

Bahan utama pembuatan sirup adalah buah mangrove Sonneratia caseolaris (nama lokal: pedada) yang diambil dari kawasan wisata mangrove Gunung Anyar di kelurahan Medokan 
Sawah Surabaya, Provinsi Jawa Timur. Bahanbahan lain yang digunakan meliputi sukrosa $\left(\mathrm{C}_{12} \mathrm{H}_{22} \mathrm{O}_{11}\right)$ dan sodium benzoat $\left(\mathrm{C}_{7} \mathrm{H}_{5} \mathrm{NaO}_{2}\right)$.

Buah pedada yang telah dicuci dan dikupas dipotong kecil-kecil dan ditambahkan akuades (w/v; 1/1); disaring (mesh size \pm 0.1 $\mathrm{mm})$; dan diambil filtratnya. Selanjutnya, ditambahkan sukrosa ke dalam sari buah pedada (w/v; 1/1) dan diaduk sampai mendidih. Olahan sirup yang telah dimasak kemudian dimasukkan kedalam botol yang bersih dan steril. Botol selanjutnya ditutup rapat kemudian dipasteurisasi selama \pm 1 menit pada suhu $70^{\circ} \mathrm{C}$ disterilisasi dalam autoklaf suhu $121^{\circ} \mathrm{C}$ selama 15 menit. Sirup didinginkan dengan direndam di air dingin hingga suhu turun antara $25-30^{\circ} \mathrm{C}$ dan disimpan pada suhu $0^{\circ} \mathrm{C}$.

\section{Pembuatan Stok Larutan Kitosan 10\%}

Untuk menyiapkan stok larutan kitosan CKH $10 \%$ dapat dilakukan dengan cara memasukkan kitosan CKH ke dalam asam sitrat $\left(\mathrm{C}_{6} \mathrm{H}_{8} \mathrm{O}_{7}\right) 10 \%$ (w/v; 1/10) untuk mempermudah kelarutan kitosan. Larutan kemudian distirer selama 48 jam menggunakan stirer (Magnetik Stirer PG VG Eliquid Ejuice, Indonesia) pada 6800 RPM selanjutnya stok larutan kitosan ditambahkan kedalam sirup buah mangrove sesuai dengan perlakuan.

\section{Pengamatan Uji McFarland}

Untuk melakukan pengamatan kekeruhan bakteri, dilakukan cara membandingkan standard McFarland 0,5-10 dengan turbiditas kultur bakteri, kemudian dipilih standar McFarland dengan turbiditas serupa. Menurut Aviany dan Pujiyanto (2020), untuk standar yang digunakan di Laboratorium Mikrobiologi Klinik ialah Standar McFarland 0,5. Standar tersebut merupakan dasar yang digunakan untuk percobaan kerentanan akan antimikroba dan percobaan hasil biakan bakteri. standar tersebut sebanding dengan nilai perkiraan suspensi bakteri yaitu $1,5 \times 108 \mathrm{CFU} / \mathrm{ml}$.

\section{Tahapan Uji Hedonik}

Uji organoleptik yang dilakukan adalah uji kesukaan (hedonik) berupa pengujian aroma dan warna yang dilakukan setiap 5 hari sekali kepada 3 orang panelis yang diawali pada dari hari ke-0 hingga hari ke-30 dengan menggunakan uji skala 1-9 (Tabel 1). Panelis melakukan uji secara sensori sampel sirup yang telah disiapkan pada botol sampel dan melakukan penilaian yang ditentukan melalui form kuisioner. Panelis pada umumnya telah mengenal produk sirup mangrove dengan cukup baik dan pernah mengkonsumsi sebelumnya

Tabel 1. Tingkat penilaian panelis

\begin{tabular}{cc}
\hline $\begin{array}{c}\text { Tingkat } \\
\text { Penilaian }\end{array}$ & Parameter \\
\hline 9 & Amat sangat suka \\
8 & Sangat suka \\
7 & Suka \\
6 & Agak suka \\
5 & Netral \\
4 & Agak tidak suka \\
3 & Tidak suka \\
2 & Sangat tidak suka \\
1 & Sangat amat tidak suka \\
\hline
\end{tabular}

\section{Uji FTIR}

Identifikasai senyawa dilakukan menggunakan instrumen Spektrofotometer Infra Merah (FT-IR); (SHIMADZU ; IR Spirit-T; A22415801432 AE Windows (KRS-5H, PKG); Kyoto, Japan)

\section{Rancangan Penelitian}

Penelitian dilakukan secara eksperimental dengan menggunakan metode Rancangan Acak Lengkap (RAL) dengan 7 perlakuan dengan 3 pengulangan. Dengan rincian; 5 perlakuan sampel penambahan kitosan $\mathrm{CKH}$ dan 2 perlakuan kontrol (negatif dan positif) sehingga diperoleh 21 unit percobaan. Adapun perlakuan penambahan kitosan cangkang kerang hijau (CKH) pada sirup pedada adalah sebagai berikut: P1 (penambahan larutan kitosan CKH 0,1 $\mathrm{ml})$

P2 (penambahan larutan kitosan CKH 0,2 $\mathrm{ml})$

P3 (penambahan larutan kitosan $\mathrm{CKH}$ 0,3 $\mathrm{ml})$

P4 (penambahan larutan kitosan $\mathrm{CKH}$ 0,4 $\mathrm{ml})$

P5 (penambahan larutan kitosan $\mathrm{CKH}$ 0,5 $\mathrm{ml})$

P6 (kontrol negatif atau tanpa perlakuan)

P7 (kontrol positif dengan penambahan sodium benzoat $\left.\left(\mathrm{C}_{7} \mathrm{H}_{5} \mathrm{NaO}_{2}\right) 0,1 \mathrm{ml}\right)$

Untuk menguji pengaruh pemberian larutan kitosan $\mathrm{CKH}$ terhadap sirup buah 
mangrove meliputi: uji FT-IR, uji total padatan terlarut (Brix), uji keasaman ( $\mathrm{pH})$, uji hedonik warna dan aroma, serta uji bakteri dengan menggunakan metode McFarland.

\section{Langkah Kerja Penelitian}

Botol perlakuan disterilkan dengan direbus dengan air mendidih suhu $100^{\circ} \mathrm{C}$. Sirup yang telah dipasteurisasi dimasukkan kedalam botol perlakuan sebanyak $30 \mathrm{ml}$ per botol perlakuan dan ditambahkan stok larutan kitosan sesuai perlakuan (Ellis et al, 2002). Botol perlakuan diamati pada setiap 5 hari sekali dimulai pada hari ke-0 sampai hari ke-30, parameter yang diamati meliputi organoleptik (aroma dan warna), kimia dari sirup meliputi total padatan terlarut (Brix), $\mathrm{pH}$ serta biologi dengan metode McFarland

kemudian dicatat setiap perubahan yang terjadi.

\section{Analisis Data}

Data yang telah diperoleh diolah menggunakan Ms. Excel v.2007 (Microsoft Inc, Washington, US) dan dilakukan analisis variansi (ANOVA) one way. Uji lanjut ANOVA dilakukan menggunakan metode uji beda nyata (least significance difference) menggunakan SPSS v.16 (SPSS Inc, Chicago, US).

\section{Hasil dan Pembahasan}

\section{Karakterisasi Kitosan dengan metode FTIR}

FT-IR atau Fourier Transform Infrared (FT-IR) adalah instrumen yang telah banyak digunakan untuk mengetahui spektrum vibrasi molekul yang dapat digunakan untuk memprediksi dan mengetahui struktur senyawa kimia yang terkandung dalam suatu zat. Ada tiga teknik pengukuran sampel yang banyak digunakan dalam pengukuran spektrum menggunakan FTIR yaitu Photo Acoustic Spectroscopy (PAS), Attenuated Total Reflectance (ATR), dan Difuse Reflectance Infrared Fourier Transform (DRIFT). Metode yang umum digunakan untuk pembacaan spektrum vibrasi molekul pada FTIR ada dua macam, yang pertama adalah metode reflektansi dan yang kedua adalah metode transmisi. Dalam preparasi sampel metode transmisi memerlukan teknik khusus yaitu harus dalam bentuk pellet disk (Sutton, 2011).

Dengan menentukan fraksi yang terdapat pada sampel diperlukan radiasi penyerapan pada energi dengan panjang gelombang sehingga spektrum didapatkan dengan cara melewatkan radiasi elektromagnetik inframerah melalui sampel yang telah memiliki momen dipol permanen atau diinduksi (Stuart et al, 2004; Jolanta 2010). Untuk mempersingkat waktu yang diperlukan guna memperoleh data serta peningkatan kualitas spektrum inframerah telah mengalami perkembangan transformasi Fourier Spektroskopi infra merah Fourier-Transform (FTIR) sehingga secara tidak langsung menambah benefit yang cukup baik (Smith et al, 1996; Jolanta 2010).

Analisis gugus fungsi spektrum FTIR digunakan untuk mengidentifikasi gugus fungsional yang ada pada sampel kitosan. Berikut adalah hasil uji karakterisasi gugus fungsi FTIR pada bubuk CKH disajikan dalam Gambar 1. 


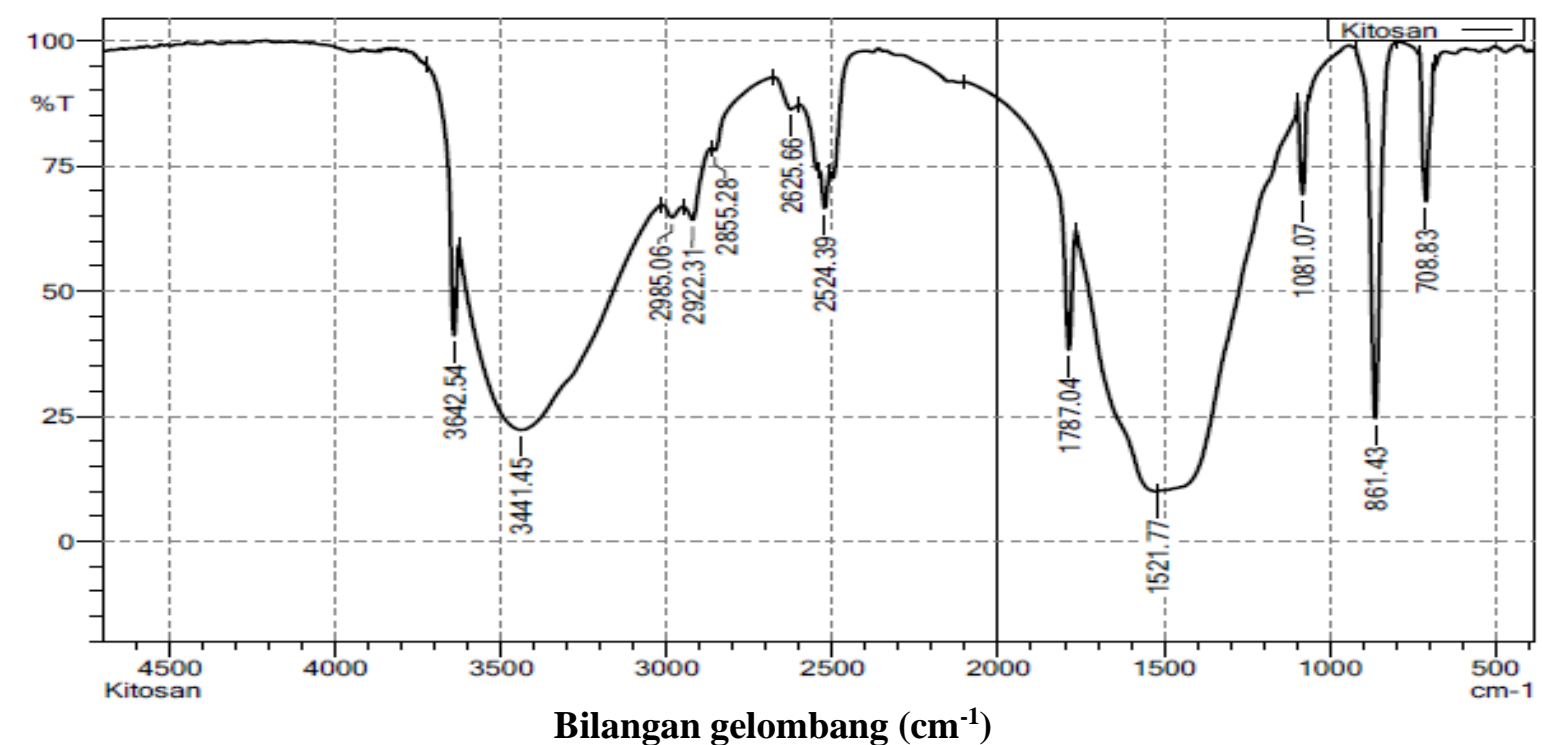

Gambar 1. Hasil uji karakteristik kitosan dengan spektrum FTIR

Berdasarkan perbandingan spektra IR kitosan standar dari Balai Riset dan Standarisasi Industri (Tabel 2), manyajikan gugus fungsi pada masing-masing bilangan gelombang tidak jauh dengan standar sehingga dapat disimpulkan bahwa senyawa hasil isolasi dari $\mathrm{CKH}$ menghasilkan kitosan yang memenuhi standar.

Tabel 2. Puncak serapan FTIR kitosan

\begin{tabular}{lcc}
\hline \multicolumn{1}{c}{ Gugus Fungsi } & \multicolumn{2}{c}{ Bilangan Gelombang $\left(\mathbf{c m}^{-\mathbf{1}}\right)$} \\
\cline { 2 - 3 } & Standar* & Hasil \\
\hline OH stretching & 3442,60 & 3642,54 \\
\hline Tumpang tindih OH (vs) NH2 & 3442,60 & 3441,45 \\
\hline NH (-NHCOCH3) stretching amida I & 3442,60 & 2985,06 \\
\hline $\mathrm{CH}(\mathrm{CH} 3)$ bending & 2992,80 & 2992,31 \\
\hline $\mathrm{C}=\mathrm{O}(-\mathrm{NHCOCH3)} \mathrm{stretching} \mathrm{amida} \mathrm{I}$ & 1660,80 & 2885,28 \\
\hline $\mathrm{NH}(-\mathrm{NHCOCH3)} \mathrm{bending} \mathrm{amida} \mathrm{II}$ & 1587,94 & 2625,66 \\
\hline $\mathrm{CN}(-\mathrm{NHCOCH3)} \mathrm{stretching}$ & 1259,54 & 2542,39 \\
\hline $\mathrm{NH}(\mathrm{R}-\mathrm{NH} 2)$ bending & 1587,94 & 1787,04 \\
\hline $\mathrm{CH}(-\mathrm{CH} 2)$ bending sym & 1377,11 & 1521,77 \\
\hline $\mathrm{C}-\mathrm{O}(-\mathrm{C}-\mathrm{O}-\mathrm{C}-$ ) stretching asym & 1154,64 & 1081,07 \\
\hline $\mathrm{C}-\mathrm{O}(-\mathrm{C}-\mathrm{O}-\mathrm{C}-$ ) stretching sym & 1026,23 & 861,43 \\
\hline$\beta-1,4-$ glikosidik & 897,41 & 708,83 \\
\hline \multicolumn{2}{c}{ *Sumber: Dompeipen $(2017)$} &
\end{tabular}

\section{Total Kepadatan Terlarut (TPT;Brix)}

Hasil analisis pengaruh penambahan ekstrak kitosan CKH pada sirup mangrove dengan berbagai variasi konsentrasi selama 30 hari pengamatan ditunjukkan pada Gambar 2.

Tabel 3. Total padatan terlarut pada sirup mangrove dengan penambahan kitosan $\mathrm{CKH}$

\begin{tabular}{cccccccc}
\hline \multirow{2}{*}{ Perlakuan } & \multicolumn{7}{c}{ Penyimpanan (Hari) } \\
\cline { 2 - 8 } & $\mathbf{0}$ & $\mathbf{5}$ & $\mathbf{1 0}$ & $\mathbf{1 5}$ & $\mathbf{2 0}$ & $\mathbf{2 5}$ & $\mathbf{3 0}$ \\
\cline { 2 - 8 } P1 & 22,36 & 22,36 & 22,26 & 22,16 & 22,1 & 22,06 & 21,4 \\
P2 & 22,43 & 22,43 & 22,3 & 22,06 & 22,03 & 21,83 & 21,3 \\
P3 & 22,46 & 22,4 & 22,3 & 22,2 & 22,1 & 22,06 & 22
\end{tabular}




\begin{tabular}{cccccccc} 
P4 & 22,43 & 22,4 & 22,3 & 22,16 & 22,16 & 22,13 & 21,7 \\
P5 & 22,46 & 22,36 & 22,3 & 22,23 & 22,13 & 22,06 & 21,8 \\
P6 & 22,36 & 22,33 & 22,2 & 22,06 & 22,13 & 22,1 & 21,73 \\
P7 & 22,43 & 22,33 & 22,26 & 22,13 & 22,06 & 22,03 & 22 \\
\hline
\end{tabular}

Gambar 2 menunjukkan bahwa perlakuan penambahan ekstrak kitosan dari CKH dengan total padatan terlarut tertinggi pada perlakuan $\mathrm{P} 3$ $\left(22,46^{\circ}\right.$ Brix $)$ hari ke-0, sedangkan perlakuan terendah didapatkan pada perlakuan kontrol P2 $\left(21,3^{\circ}\right.$ Brix $)$ pada hari ke 30 .

Penambahan tingkat konsentrasi kitosan pada sirup mangrove memberikan peningkatan Total Padatan Terlarut (TPT) yang diakibatkan sifat kimiawi kitosan yang mudah larut dalam larutan asam. Hal tersebut terjadi karena keterikatan yang cukup erat antara TPT dengan jumlah protein, lemak dan karbohidrat yang terdapat pada sirup (Mekawati dan Sumardjo,
2000). Secara umum kitosan merupakan senyawa yang sukar larut dalam air, akan tetapi dapat larut dengan sangat baik dalam larutan asam (Safitri et al, 2022). Kitosan mudah larut pada larutan asam asetat $1 \%$, asam piruvat $10 \%$ dan asam sitrat $10 \%$. Ditambahkan sedikit asam sitrat untuk menigkatkan kelarutan kitosan (Karnowska et al, 2004). Asam sitrat yang ditambahkan sangat sedikit, sehingga tidak mempengaruhi peran kitosan sebagai zat pengawet utama. Asam sitrat ditambahkan untuk membantu kelarutan kitosan dalam sirup mangrove.

\section{Total Padatan Terlarut (Brix $\left.{ }^{\circ}\right)$}

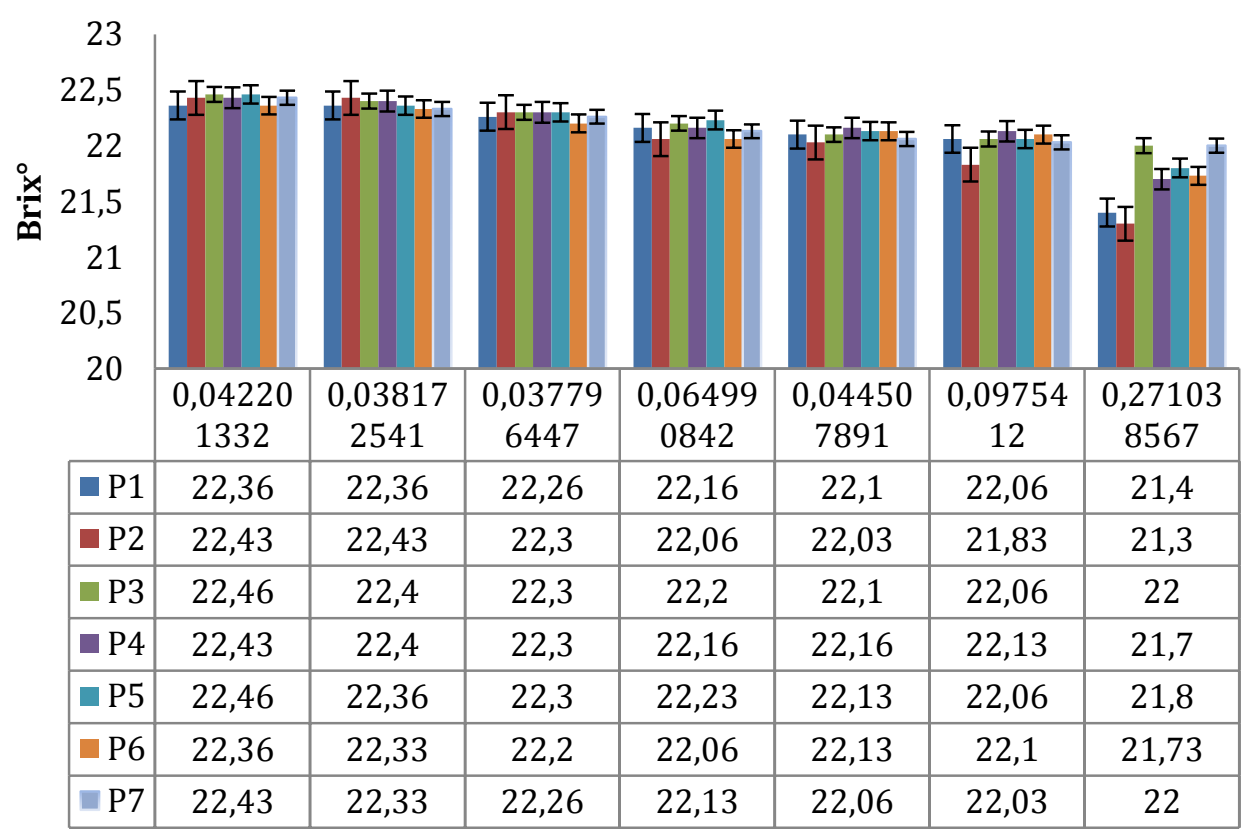

Gambar 2. Grafik Total Padatan Terlarut Pada Sirup Mangrove

Berdasarkan Gambar 3, selama penyimpanan 30 hari terjadi penurunan pada semua perlakuan. Penurunan TPT yang paling terlihat signifikan setelah hari ke-20 masa penyimpanan. Penurunan terendah terjadi pada hari ke 30.

Menurunnya nilai TPT menandakan terjadinya penurunan sukrosa dalam sirup. Nilai
TPT yang menurun bisa disebabkan oleh fermentasi dari mikroba. Sukrosa yang diselubungi karbohidrat menjadi konsentrat pertama yang akan dipecah oleh mikroba melalui proses fermentasi menjadi unit-unit sukrosa yang lebih sederhana (Violando dan Safitri, 2020). Jangka penyimpanan juga berpengaruh terhadap mikroba untuk mendegradasi karbohidrat 
menjadi senyawa organik (Fardiaz, 1975). Substrat akan dihidrolisis dan semakin menurun, sehingga menyebabkan penurunan TPT.

\section{Derajat Keasaman (pH)}

Berikut adalah hasil analisis penambahan kitosan $\mathrm{CKH}$ dengan dosis yang berbeda dapat dilihat pada Tabel 4.
Berdasarkan Gambar 4 nilai $\mathrm{pH}$ menurun seiring dengan lamanya penyimpanan. Hal ini sesuai dengan hasil penelitian yang menunjukkan penurunan derajat keasaman pada semua perlakuan dari P1-P7.

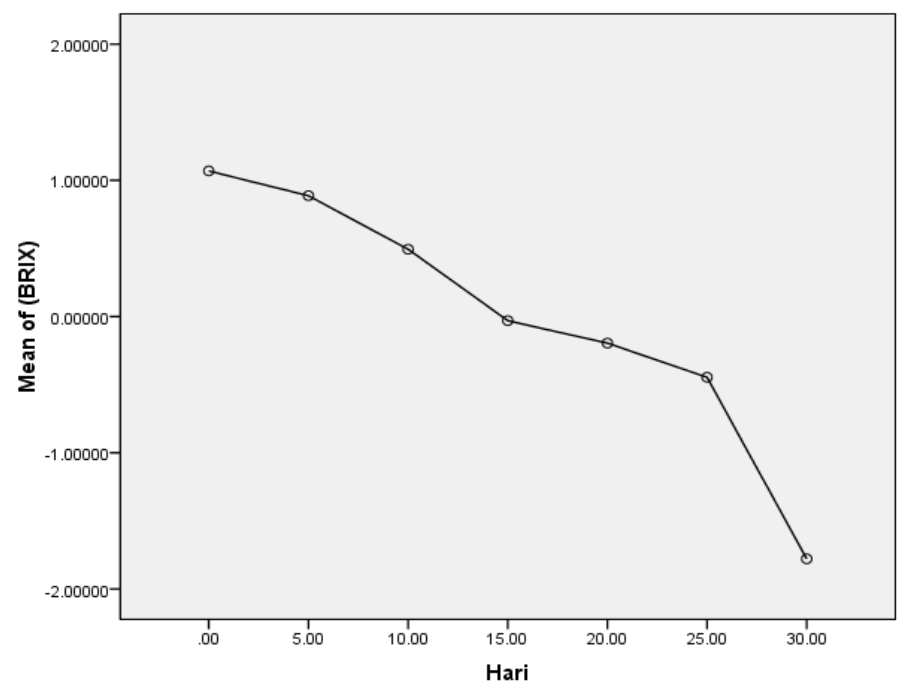

Gambar 3. Diagram TPT perlakuan selama 30 hari

Menurunnya daya ikat sari buah dan penstabil menyebabkan berkurangnya gugus karboksil selama masa penyimpanan. Terbentuknya asam yang disebabkan oleh reaksi spontan antara $\mathrm{CO}_{2}$ dengan $\mathrm{H}_{2} \mathrm{O}$ menyebabkan menurunnya nilai $\mathrm{pH}$. Karena adanya penguraian sukrosa yang diakibatkan gas $\mathrm{CO}_{2}$ yang terbentuk karena adanya aktifitas mikroba saat proses fermentasi sehingga sukrosa dirombak menjadi unit-unit yang lebih sederhana (Desrosier, 1988).

Tabel 4. Derajat keasaaman pada sirup mangrove dengan penambahan kitosan $\mathrm{CKH}$

\begin{tabular}{cccccccc}
\hline \multirow{2}{*}{ Perlakuan } & \multicolumn{7}{c}{ Penyimpanan (Hari) } \\
\cline { 2 - 8 } & $\mathbf{0}$ & $\mathbf{5}$ & $\mathbf{1 0}$ & $\mathbf{1 5}$ & $\mathbf{2 0}$ & $\mathbf{2 5}$ & $\mathbf{3 0}$ \\
\hline P1 & 2,73 & 2,6 & 2,53 & 2,43 & 2,36 & 2,16 & 2,06 \\
P2 & 2,56 & 2,53 & 2,5 & 2,4 & 2,3 & 2,16 & 2,13 \\
P3 & 2,63 & 2,53 & 2,46 & 2,4 & 2,36 & 2,3 & 2,26 \\
P4 & 2,6 & 2,5 & 2,46 & 2,36 & 2,33 & 2,13 & 2,06 \\
P5 & 2,56 & 2,53 & 2,53 & 2,4 & 2,33 & 2,23 & 2,16 \\
P6 & 3,1 & 3,1 & 3,03 & 3 & 3 & 2,9 & 2,86 \\
P7 & 2,9 & 2,83 & 2,83 & 2,73 & 2,66 & 2,66 & 2,6 \\
\hline
\end{tabular}




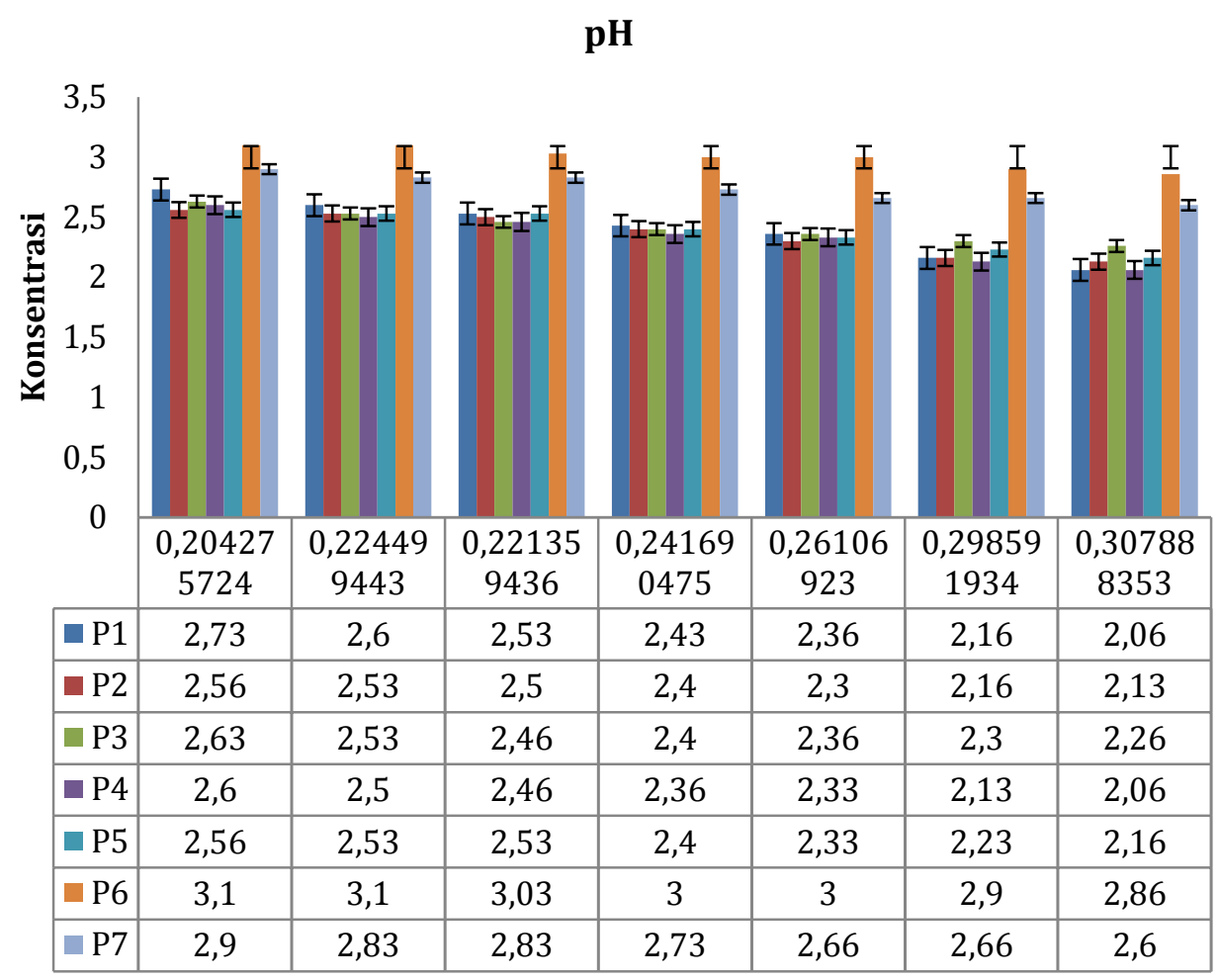

Gambar 4. Grafik derajat keasaman pada sirup mangrove

Tingkat konsentrasi kitosan yang ditambahkan akan menaikkan keasaman. Hal ini diakibatkan penambahan larutan kitosan ke dalam larutan $\mathrm{C}_{6} \mathrm{H}_{8} \mathrm{O}_{7} 10 \%$, sehingga sirup mangrove akan semakin asam. Sebagai senyawa asidulan yang bersifat masam, asam sitrat dapat digunakan untuk proses pengolahan makanan (Zhao, 2002). Salah satu benefit penambahan
$\mathrm{C}_{6} \mathrm{H}_{8} \mathrm{O}_{7}$ mempunyai tujuan untuk mempertagas warna dan aroma, selain itu juga bertujuan untuk menjaga kestabilan flavor dengan menyelubungi aftertaste yang tidak disukai serta mencegah sukrosa dari kristalisasi. Dengan ditambahkan $\mathrm{C}_{6} \mathrm{H}_{8} \mathrm{O}_{7}$ dapat menurunkan $\mathrm{pH}$ hingga turun dibawah 4,5 (Mukarromah et al, 2010).

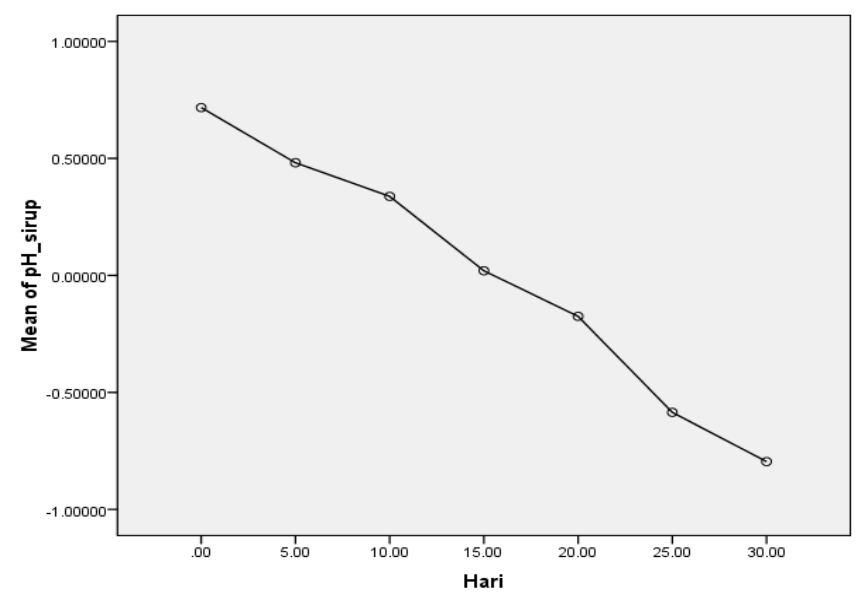

Gambar 5. Diagram derajat keasaman peralakuan selama 30 hari

Pada Gambar 5, dapat dilihat bahwa penurunan derajat keasaman yang paling terlihat signifikan dimulai pada hari ke-20. Tingkat keasaman atau kebasaan suatu larutan dapat 
dinyatakan melalui derajat keasaman (Haryadi et al, 2014). Tingkat keasaman yang tinggi $(\mathrm{pH}$ rendah) diikuti TPT yang tinggi bisa dikatakan sebagai salah satu dari teknik pengawetan makanan karena dapat mencegah pertumbuhan kapang (Mukarromah et al, 2010).

\section{Organoleptik \\ Warna}

Analisis warna diamati secara visual menggunakan uji hedonik dengan menetapkan 3 panelis yang akan menilai warna selama 30 hari dengan periode sampel 5 hari sekali dan dinilai dari parameter yang telah ditentukan. Warna merupakan penilaian yang cukup penting dalam penilaian analisa karena warna merupakan visual paling menarik yang akan memiliki daya tarik tersendiri bagi konsumen. Hasil analisa warna memberikan pengaruh yang tidak nyata pada setiap perlakuan dan cederung stabil dari hari-0 sampai dengan hari ke-30 (Gambar 6). Hasil analisa warna dapat dilihat pada Tabel 5.

Tabel 5. Rata-rata penilaian panelis terhadap warna sirup buah mangrove

\begin{tabular}{cccccccc}
\hline Pengujian & \multicolumn{7}{c}{ Penyimpanan (Hari) } \\
\cline { 2 - 8 } Sampel & $\mathbf{0}$ & $\mathbf{5}$ & $\mathbf{1 0}$ & $\mathbf{1 5}$ & $\mathbf{2 0}$ & $\mathbf{2 5}$ & $\mathbf{3 0}$ \\
\hline Sampel P1 & 5,33 & 5,33 & 5,33 & 5,66 & 5,66 & 5,33 & 5 \\
Sampel P2 & 5,66 & 5 & 5 & 5 & 5 & 5 & 5,33 \\
Sampel P3 & 6,66 & 7 & 6,66 & 6,66 & 6,66 & 6,66 & 6,66 \\
Sampel P4 & 5,33 & 5,33 & 5,66 & 5,66 & 5,33 & 5,66 & 5,66 \\
Sampel P5 & 5 & 5 & 5 & 5 & 5 & 5 & 5,33 \\
Sampel P6 & 5 & 5 & 5 & 5 & 5 & 4,33 & 3,66 \\
Sampel P7 & 5,33 & 5 & 4,66 & 4,66 & 4,66 & 4,66 & 4,66 \\
\hline
\end{tabular}

\section{WARNA SIRUP}

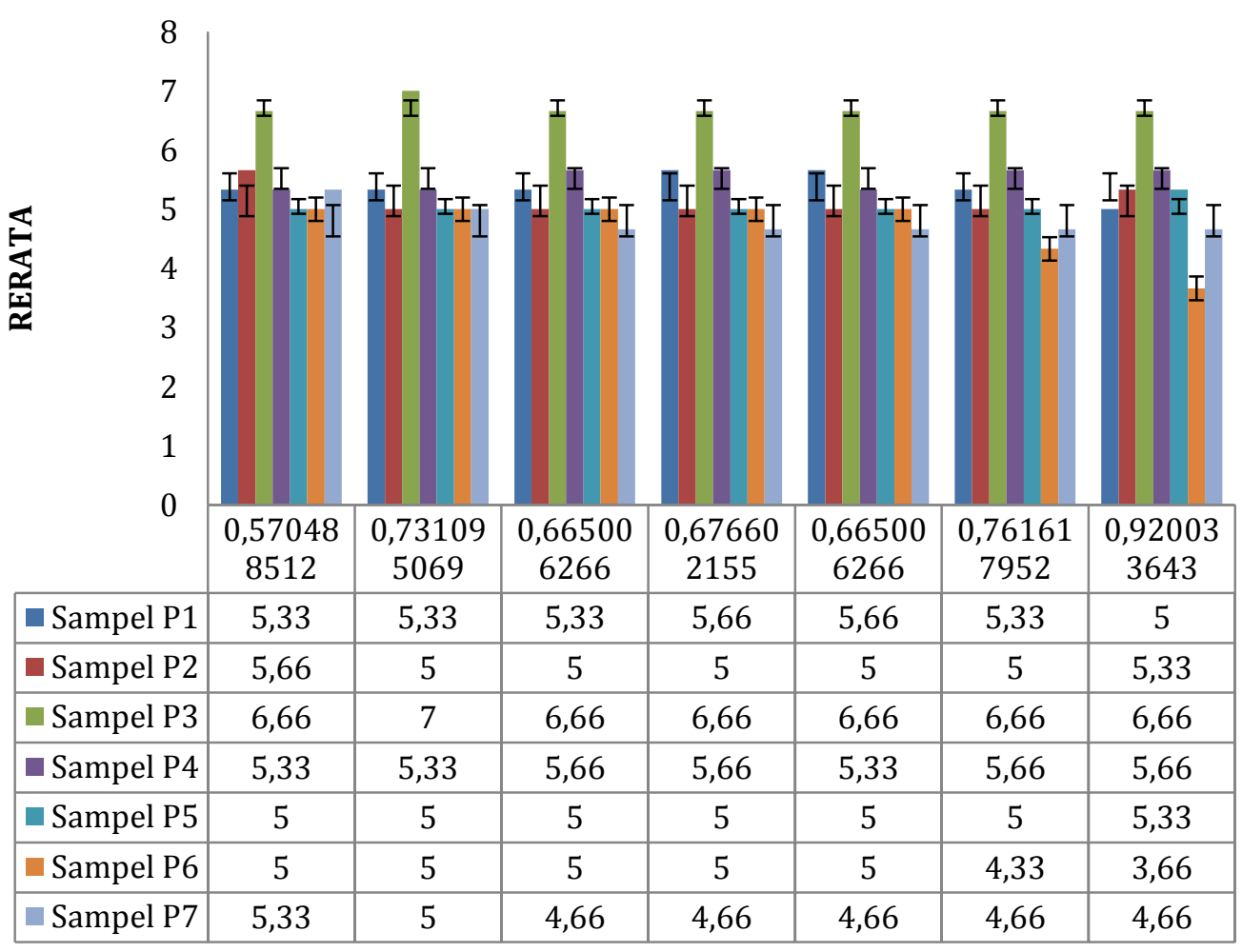

Gambar 6. Grafik penilaian panelis terhadap warna sirup buah mangrove

Berdasarkan Tabel 5 diketahui bahwa respon panelis terbaik pada perlakuan P3 pada setiap sampling yang diambil setiap 5 hari sekali.
Penilaian terbaik dari panelis dengan memilih P3 dikarenakan panelis menyukai warna sirup yang cenderung agak keruh karena panelis menilai 
sirup buah mangrove seharusnya itu memang berwarna agak kekeruhan.

Pada perlakuan P5 panelis cenderung kurang menyukai sirup mangrove dikarenakan sirup mangrove berubah warna menjadi jernih (Dian, 2003). Karena sifat kitosan yang dikenal sebagai penjernih, maka semakin tinggi larutan kitosan CKH yang ditambahkan, sirup mangrove akan semakin jernih (Rogis, 2007). Warna sirup kurang menarik bagi panelis karena sirup mangrove yang seharusnya berwarna kemerahmerahan. Sesuai penelitian Zahiruddin (2008) pencampuran kitosan dan hemiselulase dapat menjernihkan sirup dengan baik.

\section{Aroma}

Berdasarkan nilai uji aroma sirup buah mangrove, dari semua perlakuan P1-P5 panelis rata-rata memberikan nilai netral pada setiap perlakuan (Tabel 6).

Tabel 6. Rata-rata penilaian panelis terhadap aroma sirup buah mangrove

\begin{tabular}{cccccccc}
\hline Pengujian & \multicolumn{7}{c}{ Penyimpanan (Hari) } \\
\cline { 2 - 8 } Sampel & $\mathbf{0}$ & $\mathbf{5}$ & $\mathbf{1 0}$ & $\mathbf{1 5}$ & $\mathbf{2 0}$ & $\mathbf{2 5}$ & $\mathbf{3 0}$ \\
\hline Sampel P1 & 5 & 5 & 5,33 & 5 & 5 & 5 & 5 \\
Sampel P2 & 5,66 & 5,33 & 5,33 & 5,66 & 5,33 & 5 & 5 \\
Sampel P3 & 6 & 5,66 & 5,66 & 5,66 & 6 & 5,66 & 5,33 \\
Sampel P4 & 5,33 & 5 & 5 & 5 & 5 & 5,33 & 5 \\
Sampel P5 & 5 & 5 & 5 & 4,66 & 4,33 & 4,33 & 4,33 \\
Sampel P6 & 5 & 4,66 & 4,33 & 4,33 & 4 & 3,33 & 3 \\
Sampel P7 & 5,33 & 5,66 & 5,66 & 6 & 6 & 5,66 & 5,33 \\
\hline
\end{tabular}

AROMA SIRUP

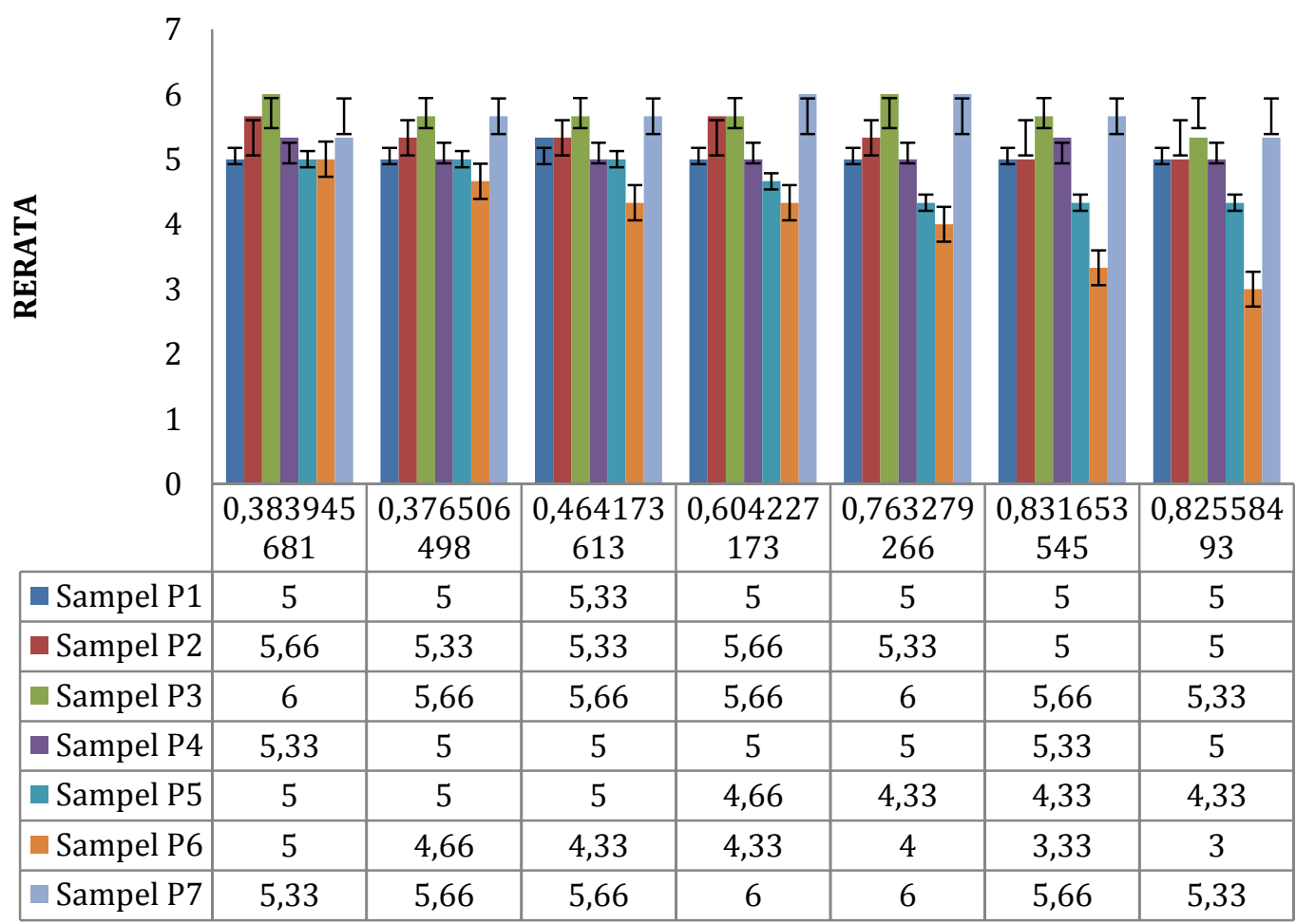

Gambar 6. Grafik penilaian panelis terhadap aroma sirup buah mangrove 
Dari Gambar 6 dijelaskan rata-rata panelis menyukai aroma pada perlakuan P3. Perlakuan P3 dinilai lebih memiliki aroma yang sama dengan kontrol positif yang ditambahkan pengawet sodium benzoat. Menurut panelis aroma P3 lebih segar dibandingkan dengan perlakuan P1, P2, P4 dan P5. Penilaian panelis agak tidak suka pada perlakuan P5 disebabkan karena dengan konsentrasi perlakuan yang tinggi panelis menilai aroma sirup berubah.

Menurunnya kesukaan panelis terhadap aroma sirup dikarenakan tingkat konsentrasi kitosan yang ditambahkan pada sirup mangrove. Hal ini disebabkan karena kitosan akan mengikat partikel-partikel aroma pada sirup mangrove. Kandungan zat-zat volatil yang dimiliki oleh buah akan memberikan aroma segar pada buah, sehingga tingkat kesukaan panelis tergantung pada aroma buah yang digunakan. Penilaian aroma juga disebabkan sifat-sifat pada bahan pangan. Aroma menjadi salah satu parameter yang akan memberikan tingkat kepercayaan panelis akan rasa enak atau tidaknya suatu makanan. Aroma yang umum diterima oleh indera penciuman dan otak cenderung aroma utama seperti harum, asam, tengik dan hangus (Zhao, 2002)

\section{Uji McFarland}

Dalam penelitian ini pengujian bakteri menggunakan metode McFarland. McFarland bisa digunakan untuk menggantikan perhitungan bakteri dengan memperkirakan tingkat kepadatan sel pada pengujian antimikroba. Penyetaraan konsentrasi mikroba bisa menggunakan larutan $\mathrm{BaCl} 2$ 1\% dan $\mathrm{H} 2 \mathrm{SO} 41 \%$
(Holipah et al, 2010). McFarland umum digunakan untuk menghitung kepadatan bakteri dengan menggunakan metode spektrofotometri. Standar McFarland digunakan untuk memperkirakan konsentrasi bakteri gram negatif (Whitman and MacNair, 2004). Standar ini memiliki skala nomor 1 hingga 10 yang bertujuan untuk mengetahui konsentrasi bakteri per mili liter.

Kelebihan dari standar ini adalah tidak dibutuhkan waktu inkubasi yang lama karena dengan standar ini cukup mendapatkan tingkat kepadatan bakteri yang diinginkan. Sedangkan kerugiannya adalah terjadi perbedaan pandangan untuk menilai tingkat kekeruhan dari sel bakteri (Sutton, 2011).

\section{Pengamatan McFarland}

Untuk mengetahui turbiditas kultur bakteri dapat dilakukan pengamatan dengan membandingkan antara turbiditas kultur bakteri dengan standard McFarland 0,5-10. Caranya dengan memilih standar McFarland dengan turbiditas yang sama dengan bakteri dan hasilnya bisa dilihat tabel skala McFarland. Contohnya, jika turbiditas bakteri sama dengan standard McFarland skala nomor 2, maka kepadatan bakteri tersebut $600 \times 10^{-6} / \mathrm{ml}$.

Data analisis uji McFarland menunjukkan angka yang stabil hari ke-0 hingga hari ke-30 pada perlakuan P2, P3, P4, P5, P7. Sedangkan untuk perlakuan P1 pada hari ke-30 menunjukkan terjadinya perubahan skala menjadi $600 \times 10^{-6}$. Sedangkan untuk sampel sirup kontrol negatif P6 sudah terjadi perubahan pada skala pada hari ke-15 (Tabel 8).

Tabel 7. Hasil uji bakteri dengan metode McFarland

\begin{tabular}{cccccccc}
\hline \multirow{2}{*}{ Perlakuan } & \multicolumn{7}{c}{ Penyimpanan (Hari) } \\
\cline { 2 - 7 } P1 & $\mathbf{0}$ & $\mathbf{5}$ & $\mathbf{1 0}$ & $\mathbf{1 5}$ & $\mathbf{2 0}$ & $\mathbf{2 5}$ & $\mathbf{3 0}$ \\
\cline { 2 - 7 } P2 & $300 \times 10^{-6}$ & $300 \times 10^{-6}$ & $300 \times 10^{-6}$ & $300 \times 10^{-6}$ & $300 \times 10^{-6}$ & $300 \times 10^{-6}$ & $600 \times 10^{-6}$ \\
P3 & $300 \times 10^{-6}$ & $300 \times 10^{-6}$ & $300 \times 10^{-6}$ & $300 \times 10^{-6}$ & $300 \times 10^{-6}$ & $300 \times 10^{-6}$ & $300 \times 10^{-6}$ \\
P4 & $300 \times 10^{-6}$ & $300 \times 10^{-6}$ & $300 \times 10^{-6}$ & $300 \times 10^{-6}$ & $300 \times 10^{-6}$ & $300 \times 10^{-6}$ & $300 \times 10^{-6}$ \\
P5 & $300 \times 10^{-6}$ & $300 \times 10^{-6}$ & $300 \times 10^{-6}$ & $300 \times 10^{-6}$ & $300 \times 10^{-6}$ & $300 \times 10^{-6}$ & $300 \times 10^{-6}$ \\
P6 & $300 \times 10^{-6}$ & $300 \times 10^{-6}$ & $300 \times 10^{-6}$ & $300 \times 10^{-6}$ & $300 \times 10^{-6}$ & $300 \times 10^{-6}$ & $300 \times 10^{-6}$ \\
P7 & $300 \times 10^{-6}$ & $300 \times 10^{-6}$ & $300 \times 10^{-6}$ & $600 \times 10^{-6}$ & $600 \times 10^{-6}$ & $600 \times 10^{-6}$ & $600 \times 10^{-6}$ \\
& $300 \times 10^{-6}$ & $300 \times 10^{-6}$ & $300 \times 10^{-6}$ & $300 \times 10^{-6}$ & $300 \times 10^{-6}$ & $300 \times 10^{-6}$ & $300 \times 10^{-6}$ \\
\hline
\end{tabular}

Dapat disimpulkan dari data yang diperoleh bahwa pengaruh penambahan stok larutan kitosan berlaku pada semua perlakuan kecuali pada perlakuan dengan konsentrasi paling rendah $\mathrm{P} 1$ pada hari ke-30 dan perlakuan negatif P6 pada hari ke 15-30 dimana skala McFarland berubah menjadi $600 \times 10^{-6}$. Dengan konsentrasi yang lebih tinggi kitosan dari $\mathrm{CKH}$ 
ini mampu menghambat pertumbuhan bakteri yang tumbuh pada sirup buah mangrove.

\section{Kesimpulan}

Perubahan statistik terhadap total padatan terlarut, $\mathrm{pH}$, dan organoleptik pada sirup setelah ditambahkan larutan kitosan dengan konsentrasi yang berbeda. Data hasil penelitian menunjukkan bahwa perlakuan dengan angka yang konsistensi pada perlakuan P3 dengan penambahan kitosan $0,3 \mathrm{ml}$. Rata-rata total padatan terlarut yang diperoleh 22,46-22,20, derajat keasaman $(\mathrm{pH})$ 2,63-2,40 dengan organoleptik para panelis memberikan nilai netral pada sampel warna dan aroma.

Uji McFarland pada skala 1 pada perlakuan P2, P3, P4, P5, P7. Sedangkan untuk perlakuan P1 pada hari ke-30 menunjukkan terjadinya perubahan skala menjadi $600 \times 10^{-6}$. Sedangkan untuk sampel sirup kontrol negatif P6 sudah terjadi perubahan pada skala $600 \times 10^{-6}$. pada hari ke-15, serta tidak terjadi pengendapan. Penggunaan kitosan pada sirup pedada harus dilarutkan dulu dengan asam sitrat, karena sifat kitosan yang mudah larut pada larutan asam.

\section{Ucapan Terima Kasih}

Penulis menyampaikan terima kasih kepada Dinas Ketahanan Pangan dan Pertanian (DKPP) Kota Surabaya yang telah memperkenalkan kepada Bapak Shodik, petugas kawasan wisata mangrove Gunung Anyar di kelurahan Medokan Sawah Surabaya, Provinsi Jawa Timur untuk memperoleh buah mangrove yang digunakan untuk penelitian. Penulis pertama juga menyampaikan ucapan terima kasih kepada Dekan Fakultas Pertanian Universitas Muhammadiyah Gresik yang telah memfasilitasi laboratorium untuk pelaksanaan penelitian serta teman-teman angkatan tahun 2018 Program Studi Budidaya Perikanan Fakultas Pertanian Universitas Muhammadiyah Gresik.

\section{Referensi}

Acosta, V., Glem, M.E., Natera, Y., Urbano, T., Himmelman, J.H., Rey-Méndez, M. \& Lodeiros, C., (2009). Differential growth of the mussels Perna perna and Perna viridis (Bivalvia: Mytilidae) in suspended culture in the Golfo de Cariaco, Venezuela. Journal of the World Aquaculture Society, 40(2), pp.226-235.

Affandi, R., \& Tang, U. (2002). Fisiologi Hewan Air. Riau: University Riau Press

Arini, L. D. D. (2017). Faktor-faktor Penyebab dan Karakteristik Makanan Kadaluarsa yang Berdampak Buruk pada Kesehatan Masyarakat. Jurnal Teknologi dan Industri Pangan, 2(1):15-24.

Ariyani F \& Yennie Y. (2008). Pengawet Pindang Ikan Layang (Decapterus russelli) menggunakan Kitosan. Jurnal Pascapanen dan Bioteknologi Kelautan dan Perikanan, 3(2): 139-146.

Aviany, HB., \& Pujiyanto, S. (2020). Analisis Efektivitas Probiotik di Dalam Produk Kecantikan sebagai Antibakteri terhadap Bakteri Staphulococcus epidermidis. Berkala Bioteknologi. 3(2): 1-8.

Costa-Pierce, B.A., (2008). An ecosystem approach to marine aquaculture: a global review. Building an ecosystem approach to aquaculture, pp.81-115.

Dompeipen, EJ. (2017). Isolasi dan Identifikasi Kitin dan Kitosan dari Kulit Udang Windu (Penaeus monodon) Dengan Spektroskopi Inframerah. Journal Kemenperin, pp.39.

Desrosier, N.W. (1988). Teknologi Pengawetan Pangan. Terjemahan Muchji Muljoharjo. UI Press. Jakarta.

Dian, K. (2003). Penjernihan sirup pala menggunakan kemiselulase dan kitosan. [Skripsi]. Bogor (ID): Institut Pertanian Bogor.

Ellis, J., Cummings, V., Hewitt, J., Thrush, S. \& Norkko, A., (2002). Determining effects of suspended sediment on condition of a suspension feeding bivalve (Atrina zelandica): results of a survey, a laboratory experiment and a field transplant experiment. Journal of Experimental Marine Biology and Ecology, 267(2), pp.147-174.

Fardiaz, S. (1975). Mikrobiologi Pangan I. Gramedia Pustaka Utama. Jakarta.

Hajji, S., Younes, I., Ghorbel-Bellaaj, O., Hajji, R., Rinaudo, M., Nasri, M., \& Jellouli, K. (2014). Structural differences between chitin and chitosan extracted from three different marine sources. Int. J. Biol. Macromol 65 : 298-306. 
Hargono., Abdullah., \& Sumantri, I. (2008). Pembuatan Kitosan dari Limbah Cangkang Udang serta Aplikasinya dalam Mereduksi Kolesterol Lemak Kambing, J Reaktor 12(1):53-57.

Haryadi, Rossi E, \& Harun N. (2014). Pengaruh penambahan kitosan sebagai pengawet alami pada pembuatan sirup buah naga (Hylocereus polyrhizus). Jurnal Pangan. 1 (2): $13-18$.

Holipah, S. N., Wijayanti, E. \& Saputra, V. (2010). Aplikasi Kitosan Sebagai Pengawet Alami Dalam Meningkatkan Mutu Simpan Produk Pasca Panen. PKM Gagasan Tertulis. Institut Pertanian Bogor. Bogor.

Islem, Y., \& Marguerite, R. (2015). Chitin and chitosan preparation from marine sources. structure, properties and applications. Mar. Drugs 13 : 1133-1174.

Jolanta, K., Małgorzata, M., Zbigniew, K., Anna B., Krzysztof, B., Jorg, T., and Piotr, S. (2010). Application of spectroscopic methods for structural analysis of chitin and chitosan. Mar. Drugs 8 : 1567-1636.

Kusumaningrum, A., D. Ariani, \& Y. Khasanah. (2017). Pengaruh Waktu Penyimpanan Terhadap Karakteristik Makanan Tradisional "Jenang Saban." Jurnal Penelitian Teknologi Industri. 9(1): 23-36.

Karnowska EJ. (2004). Some aspects of nitrogen, carbon and calcium accumulation in mollusks from the Zegrzynski reservoir ecosystem. Polish Journal of Enviromental Studies 14(2): 173-177

Loekman, N.A., Manan, A., Arief, M. \& Prayogo, P., (2018). Teknik Pendekatan Kerang Abalon (Haliotis squamata) di balai besar penelitian dan pengembangan budidaya laut gondol-bali. Journal of Aquaculture and Fish Health, 7(2), pp.7883.

Minda, A., Jon Efendi, Erda Syofyeni, Rahmi Marfa Lesi, \& Sri Novalina (2010). Pengaruh konsentrasi $\mathrm{NaOH}$ dan $\mathrm{KOH}$ terhadap derajat deasetilasi kitin dari limbah kulit udang. Eksakta 1 (11).

Mekawati, F. E., \& D. Sumardjo (2000). Aplikasi Kitosan Hasil Tranformasi Kitin Limbah Udang (Penaeus merguiensis) untuk Adsorpsi Ion Logam Timbal. Jurnal Sains and Matematika, FMIPA Undip. Semarang. 8 (2), hal. 51-54.

Mukarromah, Ummu, et al. (2010). Kadar Vitamin C, Mutu Fisik, pH, dan Mutu Organoleptik Sirup Rosella (Hibiscus sabdariffa, L) Berdasarkan Cara Ekstraksi. Surakarta: Jurnal Pangan dan Gizi, 01(01)

Percot, A., Viton, C., \& Domard, A. (2015). Characterization of shrimp shell deproteinization. Biomacromolecules 4 : 1380-1385.

Rogis, G., U. Made, B. \& A. Nursyah (2007). Karakteristik dan uji efikasi senyawa bahan alami chitosan terhadap patogen pasca panen antraknosa Colletotrichum musae jurnal Ilmu-ilmu Pertanian Indaonesia. IX: 58-63

Safitri, NM., Rahim, AA., \& Firmani, U. (2022). Comparison of Chitosan Characterization from Mussel Shell Waste Using Varying Concentration of Solvents. Kontribusia: Research Dissemination for Community Development. 5(1): 9-14.

Smith, B.C. (1996). Fundamentals of Fourier Transform Infrared Spectroscopy; CRC Press: Boca Raton, FL, USA.

Stuart, B.H. (2004). Infrared Spectroscopy: Fundamentals and Applications (Analytical Techniques in the Sciences $($ AnTs) *); Chichester, UK : John Wiley $\&$ Sons Ltd.

Sutton, S. (2011). Determination of Inoculum for Microbiological Testing. Summer Vol. 15 Number 3

Tanasale MFJDP, Killay A, \& Laratmase MS, (2012). Kitosan dari Limbah Kulit Kepiting Rajungan Sidoarjo, Jawa Timur. Tesis. Fakultas Biologi Universitas Gadjah Mada

Violando, WA., \& Safitri, NM. (2020). Minimum Inhibitory Concentration of Antimicrobial Sulfated Polysaccharides of Sargassum cristaefolium Against Bacillus subtilis. Journal of Applied Biological Sciences. 14(2): 136-144.

Zahiruddin. W., A. C. Erungan \& I. Wiraswanti (2008). Pemanfaatan karagenan dan kitosan

Zhao F, Yin Y, Lu W, Leong J, Zhang W, Zhang J, Zhang M, \& Kangde K. (2002). Preparation and histological evaluation of biomimetic three- 
Al Ayyubi, et al. (2022). Jurnal Biologi Tropis, 22 (1): 251 - 264

DOI: http://dx.doi.org/10.29303/jbt.v22i1.3353

dimensionalhydroxyapatite/chitosan gelation network composite scaffolds.

Biomaterials 23:3227-3234. 